\title{
PENGARUH UKURAN PERUSAHAAN, RETURN ON EQUITY (ROE), KEBIJAKAN DEVIDEN TERHADAP NILAI PERUSAHAAN SEKTOR MAKANAN DAN MINUMAN YANG TERDAFTAR DI BURSA EFEK INDONESIA TAHUN 2011-2016
}

\author{
Eni Riyawati ${ }^{1}$, Tutik Yuliani ${ }^{2}$, Ashari Sofyaun ${ }^{3}$ \\ Universitas Balikpapan $^{1}$, Universitas Balikpapan ${ }^{2}$, Universitas Balikpapan ${ }^{3}$ \\ pos-el : eniriyawati88@gmail.com ${ }^{1}, \underline{\text { tutik.yuliani@uniba-bpn.ac.id }}{ }^{2}, \underline{\text { ashari.sofyaun@uniba-bpn.ac.id }^{3}}$
}

\begin{abstract}
ABSTRAK
Penelitian ini bertujuan untuk menganalisis pengaruh Ukuran Perusahaan, Return on Equity (ROE), Kebijakan Deviden terhadap Nilai Perusahaan Sektor makanan dan minuman yang terdaftar di Bursa Efek Indonesia Tahun 2011-2016. Metode pengambilan data yang digunakan adalah purpose sampling. Penelitian ini menggunakan analisis regresi linear berganda dengan signifikan alpha 0,05. Hasil penelitian menunjukkan Ukuran Perusahaan dan Kebijakan deviden tidak berpengaruh terhadap Nilai Perusahaan sedangkan Return on Equity (ROE) berpengaruh yang signifikan terhadap Nilai Perusahaaan dan Secara bersama-sama Ukuran Perusahaan, Return on Equity (ROE) dan Kebijakan Deviden berpengaruh terhadap Nilai Perusahaan.
\end{abstract}

\section{Kata kunci : Ukuran Perusahaan, Return on Equity (ROE), Kebijakan deviden dan Nilai Perusahaan}

\section{ABSTRACT}

This Study Aims to Analiyze the Effect of Firm Size, Return on Equity (ROE), and Devidend Policy on The Value of The Food and Beverage sector Companies Listed on The Indonesian Stock Exchage in 2011-2016. The data Retrieval Method used in Purpose Sampling. This Study uses Multiple Regression Linear Analysis with Alpha Significance of 0,05. The result of the study show that the Size of the Company and Devidend Policy do not affect the Value of the Company while Return on Equity (ROE) has a Significant affect on the Value of the Company and together the Size of Company, Return on Equity (ROE), and Devidend Policy affect the Value of the Company.

\section{Keyword : Company Size, Return on Equity (ROE), Devidend Policy, and The Value of the Company}

\section{PENDAHULUAN}

Tujuan utama perusahaan yang telah go public adalah meningkatkan kemakmuran pemilik atau para pemegang saham melalui peningkatan nilai perusahaan (Salvatore, 2005). Bagi investor, nilai perusahaan merupakan konsep penting karena nilai perusahaan merupakan indikator bagaimana pasar menilai perusahaan secara keseluruhan. Tingginya Price Book Value (PBV) pada setiap periode dapat meningkatkan perusahaan menjadi besar yang tercerminkan besarnya kekayaan 
perusahaan. Ukuran perusahaan adalah besar kecilnya perusahaan dapat diukur dengan total aktiva/ besar harta perusahaan dengan menggunakan perhitungan nilai logaritma total aktiva. Dari berbagai definisi tersebut, maka dapat disimpulkan bahwa ukuran perusahaan merupakan ukuran dari besar atau kecilnya suatu perusahaan yang dapat dilihat dari berbagai skala dan ukuran perusahaan dapat diukur berdasarkan pada total aktiva perusahaan dan dapat menentukan tingkat kemudahan untuk memperoleh dana yang berasal dari pasar modal dalam suatu perusahaan. Menurut Eno Fuji Asatriani (2014) ukuran perusahaan yang besar tidak memberikan keyakinan para investor untuk menanamkan modalnya sehingga tidak berpengaruh terhadap nilai perusahaaan.

Faktor lain yang mempengaruhi nilai perusahaan adalah profitabilitas. Dalam penelitian ini profitabilitas diukur menggunakan ROE. Return on Equity (ROE) merupakan rasio yang mengukur banyaknya keuntungan yang akan diperoleh oleh pemilik modal sendiri atas investasi yang telah dilakukan. Semakin besar ROE yang dihasilkan perusahaan maka semakin baik pula kinerja perusahaan. dapat dikatakan bahwa investor menilai kinerja perusahaan dengan memperhatikan kinerja manajemen dalam mengelola investasi secara efektif, dan investor juga memperhatikan kemampuan manajemen dalam memperoleh laba bersih dengan mengelola sumber dana pembiayaan secara efektif. Menurut Maryam,Siti (2014) Tingginya Nilai ROE dapat meningkatkan nilai perusahaan. Nilai perusahaan yang tinggi akan tercermin dari harga saham perusahaan karena harga saham merupakan cerminan dari nilai asset yang dimiliki oleh perusahaan.

Kemampuan peusahaan membayar dividen berpengaruh pada tinggi rendahnya harga saham. Semakin besar perusahaan membayar dividen maka harga saham juga tinggi hal ini membuat nilai perusahaan tinggi. Kebijakan dividen terkait dengan keputusan apakah laba yang diperoleh perusahaan akan dibagikan kepada pemegang saham sebagai dividen atau ditahan dalam bentuk laba ditahan guna pembiayaan investasi dimasa datang. Jika perusahaan memperoleh laba yang besar, maka kemampuan membayar dividen juga besar. Oleh karena itu, dengan dividen yang besar akan meningkatkan nilai perusahaan. Namun kenyataannya masih sering dijumpai laba ditahan pada perusahaan sector makanan dan minuman,

yang seharusnya dibayarkan kepada pemegang saham sebagai deviden. Laba tersebut ditahan dengan tujuan ingin menambah modal operasional perusahaan tersebut karena perusahaan melakukan ekspansi usahanya yang tentunya membutuhkan modal dari laba yang ditahan tersebut dan akan dibayarkan pada periode berikutnya.

Menurut Dani Sugiarti menyatakan bahwa kebijakan deviden yang besar belum menentukan nilai perusahaan karena kemungkinan hasil laba yang besar tersebut belum dibagikan kepada para investor. Peneliti mencoba mengunakan data laporan keuangan yang diperoleh dari website resmi Bursa Efek Indonesia pada perusahaan Sektor Makanan dan Minuman Tahun 2011-2016.

\section{METODE PENELITIAN}

Pengambilan data diperoleh melalui website Indonesian Stock Exchange (IDX) 
yaitu www.idx.co.idPemilihan sampel dilakukan berdasarkan metode Purposive Sampling, yaitu pemilihan sampel saham perusahaan selama periode penelitian berdasarkan kriteria tertentu. Sesuai dengan kriteria tersebut, sampel yang diambil penulis dalam penelitian ini adalah sebanyak 60 laporan keuangan dari 10 Perusahaan Makanan dan Minuman yang terdaftar di Bursa Efek Indonesia (BEI) tahun 2011-2016.

Penelitian ini menggunakan Analisis regresi linear berganda. Persamaan model regresi digunakan untuk mengetahui pengaruh variabel $\mathrm{X}$ terhadap Variabel $\mathrm{Y}$. Berdasarkan pengujian data, hasil regresi berganda untuk menguji pengaruh Firm Size, ROE, dan DPR terhadap nilai perusahaan. Bentuk umum persamaan regresi linier berganda adalah:
$\mathrm{Y}=\alpha+\mathrm{B} 1 . \mathrm{X} 1+\mathrm{B} 2 . \mathrm{X} 2+\mathrm{B} 3 \mathrm{X} 3+\mathrm{e}$

dimana:

$\mathrm{Y}=$ Variabel dependen

$a=$ Konstanta

$\mathrm{B}=$ Koefisien Regresi

$X I=$ Variabel Ukuran Perusahaan

$\mathrm{X} 2=$ Variabel Return On Equity

$\mathrm{X} 3=$ Variabel Devidend Payout Ratio

$\mathrm{e}=$ Kesalahan Penganggu (error)

\section{HASIL DAN PEMBAHASAN}

\section{Uji analisis prasyarat}

Uji Normalitas.

Pada penelitian ini uji normalitas dilakukan dengan menggunakan uji kolmogrovsmirnov. Dengan menggunakan SPSS diperoleh hasil uji normalitas sebagai berikut:

Tabel hasil uji normalitas

\begin{tabular}{|l|l|l|}
\hline & & $\begin{array}{l}\text { Standardized } \\
\text { Residual }\end{array}$ \\
\hline $\mathrm{N}$ & & 60 \\
\hline $\begin{array}{l}\text { Norm } \\
\text { Parametersa,b }\end{array}$ & Mean & .0000000 \\
\hline & Std. Devitiation & .97424460 \\
\hline & Absolute & .097 \\
\hline $\begin{array}{l}\text { Most Extreme } \\
\text { differences }\end{array}$ & Positive & .080 \\
\hline & Negative & -.097 \\
\hline Test Statistic Sig. (2- & & .097 \\
\hline $\begin{array}{l}\text { Aymr } \\
\text { tailed, }\end{array}$ & & $.200^{\text {c.d }}$ \\
\hline
\end{tabular}


Berdasarkan tabel terlihat bahwa nilai asymptotic significance yang di peroleh pada uji Kormogrov-Smirnov sebesar 0,200 di atas tingkat signifikan 0,05 (5\%) maka dapat diartikan bahwa nilai residual terdistribusi normal.

\section{Uji Heterokedastisitas}

Hal ini dikarenakan nilai Signifikansi variabel ukuran perusahaan ( X1) sebesar 0,211 lebih besar dari 0,05 . begitu juga dengan variabel Return on Equity (ROE) (X2) mempunyai nilai signifikansi sebesar 0,058 dan variabel kebijakan deviden (X3) nilai signifikansi sebesar 0,54 ketiga variabel mempunyai nilai signifikansi lebih besar dari 0,05 sehingga dapat disimpulkan bahwa model regresi tidak mengandung gejala heteroskedastisitas.

\section{Uji Multikolinearitas}

Dari table dapat diketahui bahwa nilai tolerance variabel independen Ukuran perusahaan (X1), Return on equity (ROE) (X2), dan Kebijakan deviden (X3) $>0,10$ dan untuk nilai VIFnya $<10$. sehingga dalam model regresi yang diperoleh dapat dikatakan tidak terjadi multikolinearitas.

\section{Uji Autokorelasi}

Hasil penghitungan output model summary terdapat nilai Durbin-watson sebesar 1,983. Pengambilan keputusan pada asumsi ini memerlukan dua nilai 4. Return On Equity (ROE) (X2) mempunyai nilai koefisiensi regresi bertanda positif sebesar 18.677. Hal ini menunjukkan bahwa setiap penambahan ratio ROE sebesar 1 satuan akan meningkatkan nilai perusahaan sebesar Rp 18.677 dengan asumsi bahwa nilai variabel lain tetap. Dengan kata lain dapat dilihat bahwa reaksi nilai perusahaan positif terhadap kenaikan rasio Return On Equity (ROE) bantu yang diperoleh dari tabel Durbinwatson, yaitu nilai DL dan DU, dengan $\mathrm{K}=$ jumlah variabel bebas dan $\mathrm{N}=$ ukuran sampel.

\section{Uji Analisis regresi berganda}

Dari tabel diatas diperoleh persamaan regresi berganda untuk data penelitian yang digunakan ini berdasarkan nilai koefisien regresi hasil penghitungan pada tabel diatas sebagai berikut :

$Y=200.648+3.966 X 1+18.677 X 22.8463$

Persamaan regresi linear berganda yang diperoleh dapat dijelaskan sebagai berikut

1. Nilai konstanta sebesar 200.648 menunjukkan apabila Ukuran perusahaan, Return on Equity (ROE), Kebijakan deviden bernilai 0 (konstan atau tidak mengalami perubahan), maka nilai perusahaan akan positif bernilai 200.65.

2. Ukuran perusahaan (X1) diperoleh mempunyai koefisien regresi bertanda positif sebesar 3.966 atau dibulatkan menjadi 3.97.

3. Hal ini menunjukkan bahwa setiap peningkatan $1 \%$ ukuran perusahaan akan meningkatkan nilai perusahaan sebesar Rp. 3.97 dengan asumsi bahwa nilai variable tetap.

5. Kebijakan deviden (X3) mempunyai nilai koefisiensi regresi bertanda negatif sebesar -2.846. Hal ini menunjukkan bahwa setiap kenaikan pembayaran deviden akan menurunkan nilai perusahaan sebesar $\mathrm{Rp}-2.846$ dengan asumsi bahwa variabel lain tidak berubah. Dengan kata lain dapat dilihat bahwa reaksi nilai perusahaan negatif terhadap kenaikan pembayaran deviden. 


\section{Uji Determinasi}

Tabel Uji Determinasi

\begin{tabular}{|l|l|l|l|l|}
\hline Model & $\mathrm{R}$ & $\begin{array}{l}\mathrm{R} \\
\text { Squar } \\
\mathrm{e}\end{array}$ & $\begin{array}{l}\text { Adjuste } \\
\text { d R R R } \\
\text { Square }\end{array}$ & $\begin{array}{l}\text { Std. Error } \\
\text { of the } \\
\text { Estimate }\end{array}$ \\
\hline 1 & $.623^{\mathrm{a}}$ & .388 & .355 & 18.53862 \\
\hline
\end{tabular}

Output SPSS 24

Berdasarkan hasil uji koefisien determinasi pada tabel 15 diatas, nilai koefisien korelasi kekuatan hubungan variabel Ukuran perusahaan (X1), Return On equity (ROE) (X2), dan kebijakan deviden (X3) adalah sebesar 0,623. Hal ini berarti kekuatan hubungan antara variabel independen terhadap variabel dependen cukup kuat.

\section{Uji Hipotesis}

1. Variabel ukuran perusahaan (X1) memiliki Nilai t hitung sebesar 0,739. dengan $\mathrm{t}$ tabel 2.000 dan signifikansi ukuran perusahaan sebesar 0.463 . nilai signifikansi 0.05 lebih kecil dari 0.463 dan $\mathrm{t}$ hitung lebih kecil dari $\mathrm{t}$ tabel $(0,739<2,000)$, dengan demikian diketahui bahwa ukuran perusahaan tidak berpengaruh terhadap nilai perusahaan.

2. Variabel Return on equity (ROE)(X2) memiliki Nilai t hitung sebesar 5.551. dengan $\mathrm{t}$ tabel 2.000 dan signifikansi ROE sebesar 0.000. nilai signifikansi 0.05 lebih besar dari 0.000 dan t hitung lebih besar dari $\mathrm{t}$ tabel $(5.551>2,000)$, dengan demikian diketahui bahwa return on equity (ROE) berpengaruh positif dan signifikan terhadap nilai perusahaan.
3. Variabel Kebijakan deviden memiliki Nilai t hitung sebesar - 0.894. dengan t tabel 2.0003 dan signifikansi Kebijakan deviden sebesar 0.375 . nilai signifikansi 0.05 lebih besar dari 0.375 dan $t$ hitung lebih besar dari t tabel $(0.375<2,0003)$, dengan demikian diketahui bahwa Kebijakan deviden tidak berpengaruh terhadap nilai perusahaan.

4. Menunjukan hasil uji $F$ hitung adalah sebesar 11,835 sementara nilai $\mathrm{F}$ tabel sebesar 2,769 yang artinya $F$ hitung lebih besar dari $F$ tabel sehingga hipotesis awal diterima dengan taraf signifikan adalah 0,000 yang lebih kecil dari 0,05 , artinya variabel independen Ukuran Perusahaan, Return on equity (ROE), Kebijakan deviden memiliki pengaruh linear yang kuat terhadap Nilai perusahaan. Dalam hasil penelitian ini ukuran perusahaan tidak berpengaruh terhadap nilai perusahaan hasil temuan ini dapat dilihat dari nilai thitung yang lebih kecil dari ttabel yaitu 0,739< 2,000 dengan nilai signifikan lebih besar dari0.05 yaitu 0,463. yang berarti hipotesis nya adalah $\mathrm{H} 0$ diterima dan $\mathrm{H} 1$ ditolak sehingga dapat disimpulkan bahwa ukuran perusahaan tidak berpengaruh terhadap nilai perusahaan. 
sesuai dengan hasil temuan yang sama dilakukan oleh Eno fuji Astriani (2014) yang menyatakan bahwa ukuran perusahaan tidak memiliki pengaruh terhadap nilai perusahaan. Menurut peneliti tidak berpengaruhnya ukuran perusahaan terhadap nilai perusahaan kemungkinan dikarenakan besarnya total aktiva sebagai ukuran perusahaan belum memberikan keyakinan kepada investor tentang kemampuan perusahaan dalam mengelola asset yang ada sehingga ukuran perusahaan tidak mempengaruhi nilai perusahaan.

Dalam penelitian ini Return on Equity (ROE) berpengaruh positif dan signifikan dapat dilihat dari uji hipotesis thitung lebih besar dari ttabel yaitu 5,551 > 2,000 dengan nilai signifikan lebih kecil dari 0.05 yaitu 0,000 yang berarti hipotesisnya adalah H0 ditolak dan $\mathrm{H} 2$ diterima sehingga dapat disimpulkan bahwa Return on Equity (ROE) berpengaruh positif dan signifikan terhadap nilai perusahaan. Hal ini sejalan dengan hasil penelitian terdahulu yang dilakukan oleh Maryam, Siti (2014) yang menyatakan bahwa profitabilitas (ROE) berpengaruh positif dan signifikan terhadap nilai perusahaan. Menurut peneliti, nilai ROE yang tinggi menunjukkan bahwa kinerja perusahaan meningkat sehingga dapat menghasilkan laba bersih dan hal ini dapat menarik para investor untuk menanamkan modalnya diperusahaan tersebut.

Dalam penelitian ini kebijakan deviden tidak berpengaruh terhadap nilai perusahaan. Hasil penelitian ini sejalan dengan penelitian yang dilakukan oleh Dani Sugiarti (2015), bahwa kebijakan deviden tidak berpengaruh terhadap nilai perusahaan. Hal ini dapat dilihat dari nilai thitung lebih kecil dari ttabel yaitu $-0,894<$ 0,2000 dengan signifikan lebih besar dari 0,05 yaitu 0,375 sehingga hipotesisnya adalah $\mathrm{H} 0$ diterima $\mathrm{H} 3$ ditolak dan dapat disimpulkan bahwa kebijakan deviden tidak berpengaruh terhadap nilai perusahaan hal ini sejalan dengan teori yang dikemukakan oleh (Brigham, 2004 seperti dikutip Setiawati, 2012) yaitu teori Dividend Irrelevance Theory (ketidak relevanan dividen) yang menyatakan bahwa kebijakan dividen perusahaan tidak mempunyai pengaruh terhadap nilai perusahaan maupun biaya modalnya. Peningkatan pembayaran dividen hanya dimungkinkan apabila laba yang diperoleh perusahaan juga meningkat. Keuntungan yang diperoleh atas kenaikan harga saham akibat pembayaran dividen akan diimbangi dengan penurunan harga saham karena adanya penjualan saham baru. Oleh karenanya pemegang saham dapat menerima kas dari perusahaan saat ini dalam bentuk pembayaran dividen atau menerimanya dalam bentuk capital gain. Kemakmuran pemegang saham sekali lagi tidak dipengaruhi oleh kebijakan dividen saat ini maupun dimasa datang.

Menurut peneliti dapat saya simpulkan bahwa perusahaan yang mempunyai DPR tinggi belum tentu akan memberikan deviden yang besar. Karena kemungkinan perusahaan akan menggunakan hasil labanya sebagai tambahan modal untuk memutar kegiatan perusahaan tersebut dalam bentuk laba ditahan yang akan dibayarkan di periode berikutnya.

Hasil dari nilai uji hipotesis $\mathrm{R}^{2}$ bahwa Secara bersama-sama variabel ukuran perusahaan (X1), Return on equity (ROE) (X2), Kebijakan deviden (X3) 
memiliki pengaruh terhadap variabel nilai perusahaan (Y). Hal ini dibuktikan dengan $\mathrm{F}$ hitung $>\mathrm{F}$ tabel yaitu 11,835 $>2,769$ pada nilai signifikan $0,000<0,05$ yang artinya mempunyai pengaruh yang signifikan dan dapat disimpulkan bahwa secara bersama-sama ukuran perusahaan, Return on Equity (ROE) dan kebijakan deviden berpengaruh secara signifikan terhadap nilai perusahaan.

\section{KESIMPULAN}

Tujan dari penelitian ini adalah untuk menguji pengaruh Ukuran perusahaan, Return on equity (ROE), dan Kebijakan deviden terhadapnilai perusahaan pada perusahaan sektor makanan dan minuman yang terdaftar di Bursa Efek Indonesia. hasil uji parsial menunjukkan bahwa ukuran perusahaan tidak berpengaruh terhadap terhadapnilai perusahaan, berbeda dengan Return on equity (ROE) yang berpengaruh positif dan signifikan. Sedangkan kebijakan deviden tidak berpengaruh dan negatif terhadap nilai perusahaan. Hal dipengaruhi oleh manajemen dan pengelolaan perusahaan itu sendiri belum stabil.

\section{DAFTAR PUSTAKA}

Analisa, Yangs. 2011. “ Pengaruh Ukuran Perusahaan, Leverage, Profitabilitas dan Kebijakan Deviden terhadap

Nilai Perusahaan (Studi pada perusahaan manufaktur yang terdaftar di Bursa Efek Indonesia tahun 20062009) ". Universitas Diponogoro, Semarang.

Bambang Riyanto (2011:98) dasar-dasar pembelanjaan perusahaan edisi keempat penerbit BPFE Yogyakarta
Brigham Eugene F \& Joe F.Houston. (2006). Dasar-Dasar Manajemen Keuangan.

Alih bahasa Ali Akbar Yulianto. Buku satu. Edisi sepuluh. Jakarta: Selemba Empat.

Bringham E.F. \& Houston J.F. 2011. Essentials of Financial Management: Dasar-Dasar Manajemen Keuangan. Penerjemah Ali Akbar Yulianto. Edisi Kesebelas. Edisi Indonesia. Buku I. Jakarta: Salemba Empat.

Damodaran, Aswath, “ Investment Valuation: Tools and Techniques for Determining the Value of Any Asset", John Wiley \& Sons, Inc., New York, 2002.

Dani Sugiarti (2015). Analisis Pengaruh Profitabiitas, Ukuran Perusahaan, Kebijakan deviden dan Keputusan investasi terhadap Nilai Perusahaan Pada Perusahaan LQ45 yang terdaftar di Bursa Efek Indonesia Tahun 20112014.

Eno Fuji Astriani 2014. Pengaruh Kepemilikan Manajerial, Leverage, Profitabilitas, Ukuran Perusahaan dan Investment Opportunity Set terhadap Nilai Perusahaan Studi pada perusahaan manufaktur yang terdaftar di Bursa Efek Indonesia Tahun 2009 $-2011$

Ghozali, Ahmad (2011). Aplikasi Analisis Multivarite Dengan Program IBM SPSS 19. Semarang : Universitas Diponegoro. Gujarati, Damodar. (2006) Dasar-dasar Ekonometrika. Jakarta: Erlangga.

Husnan, Suad \& Enny Pudjiastuti. 2003. Dasar-DasarManajemen

Keuangan.Edisi Kelima. UPP STIM YKPN : Yogyakarta.

Juliansyah. Noor.(2012). Metodologi Penelitian Skripsi, Tesis dan Disertasi Karya Ilmiah. Cetakan 
Kedua. Jakarta: Kencana Prenada Media.

Jusriani, Ika Fanindya \& Shiddiq Nur Rahardjo. 2013. Analisis

Pengaruh Profitabilitas, Kebijakan Deviden, Kebijakan Utang, dan

Kepemilikan Manajerial

Terhadap Nilai Perusahaan (Studi Empiris Pada Perusahaan Manufaktur yang Terdaftar di Bursa Efek Indonesia Periode 2009 - 2011). Diponegoro Journal of Accounting. Volume 2, Nomor 2, Halaman 1- 10.

Kasmir. (2012). Analisis Laporan Keuangan. Jakarta: Rajawali pers.

Sawir. 2003. "Analisis kinerja keuangan dan perencanaan keuangan perusahaan". Jakarta: PT Gramedia pustaka utama.

Setiawati, 2012, Pengaruh Struktur Aktiva, Tingkat Likuiditas, Ukuran Perusahaan, dan Profitabilitas terhadap Struktur Modal Perusahaan Manufaktur yang Tercatat di Bursa Efek Indonesia.

Soliha dan Taswan (2002). Pengaruh Kebijakan deviden terhadap Nilai Perusahaan. " Jurnal Bisnis dan Ekonomi, STIE STIKUBANK, Semarang.

Sudana, I Made. (2011). Manajemen Keuangan Perusahaan. Edisi Kedua. Jakarta: Erlangga.
Sugiyono. (2015).MetodePenelitian Kuantitatif Kualitatif Dan $R \& B$. Bandung: Alfabeta.

Suharli, Micheal ( 2006). Studi Empiris pada Faktor-faktor yang mempengaruhi Nilai Perusahaan Pada Perusahaan Go Public di Indonesia. " Jurnal Maksi Volume 6 No 1. Universitas Kristen Indonesia Katolik Atmajaya.

Supomo, bambang \&Indriantoro, nurdan (1999).Metodologi Penelitian Bisnis Untuk Akuntansi \& Manajemen. Yogyakarta : Penerbit BPFE.

Sutrisno. (2009), Manajemen Keuangan Teori, Konsep dan Aplikasi, Edisi Pertama, Cetakan Ketujuh, Penerbit Ekonisia, Yogyakarta.

Syamsuddin. Lukman (2004) Manajemen Keuangan Perusahaan. Jakarta: Raja Grafindo Persada.

Van Horne, James C. dan John M. Wachowicz, Jr., 1998, Prinsip-prinsip Manajemen Keuangan, Alih Bahasa : Heru Sutojo, Buku Dua, Edisi Kesembilan, Salemba Empat, Jakarta.

\section{Peraturan Perundang-undangan}

Undang-undang Republik Indonesia Nomor 20 Tahun 2008 Tentang Usaha Mikro, Kecil dan Menengah. 